\title{
ANALISIS PENGARUH HAMBATAN SAMPING AKIBAT AKTIVITAS TATA GUNA LAHAN DI JALAN MH. THAMRIN TANGERANG DAN JALAN RAYA SERPONG
}

\author{
Deril Kristiawan $^{1}$ dan Najid ${ }^{2}$ \\ ${ }^{1}$ Program Studi Sarjana Teknik Sipil, Universitas Tarumanagara, Jl. Letjen S. Parman No.1 Jakarta \\ Email: deril.kristiawan@gmail.com \\ ${ }^{2}$ Program Studi Sarjana Teknik Sipil, Universitas Tarumanagara, Jl. Letjen S. Parman No.1 Jakarta \\ Email:najid@ft.untar.ac.id
}

\begin{abstract}
ABSTRAK
Kemacetan lalu lintas adalah salah satu masalah yang selalu ada di kota besar dan industri khususnya Tangerang. Seperti terlihat pada ruas Jalan MH. Thamrin Tangerang dan Jalan Raya Serpong (200m) yang menjadi salah satu contoh ruas yang mengalami kemacetan .Dalam studi ini hambatan samping sangat berpengaruh pada kinerja lalu lintas, karena semakin tinggi hambatan samping akan berpengaruh terhadap volume kendaraan ,dan kecepatan kendaraan. Data yang di gunakan untuk mengetahui hambatan samping tersebut adalah dengan cara mengitung jumlah hambatan samping, volume lalu lintas,kecepatan rata-rata kendaraan dan tata guna lahan untuk mengetahui hambatan tersebut harus diadakan survey dan mengolah data hasil survey dengan cara Pearson Correlation ,agar dapat mengetahui hambatan yang paling berpengaruh pada volume dan kecepatan kendaraan. Diperoleh korelasi paling erat yaitu korelasi antara hambatan samping dengan pejalan kaki dengan $\mathrm{R}=0.95$ pada sore hari dijalan Raya Serpong.
\end{abstract}

Kata kunci: Hambatan Samping, Kemacetan, Volume Kendaraan

\section{PENDAHULUAN}

Hambatan samping adalah dampak terhadap kinerja lalu lintas yang berasal dari aktivitas samping segmen jalan. Hambatan samping sangat mempengaruhi tingkat pelayanan disuatu ruas jalan. Pengaruh yang sangat jelas terlihat adalah berkurangnya kapasitas dan kinerja jalan, sehingga secara tidak langsung hambatan samping akan berpangaruh terhadap kecepatan kendaraan yang melalui jalan tersebut. Hambatan samping yang sangat mempengaruhi kapasitas jalan yaitu, pejalan kaki, kendaraan parkir dan berhenti, kendaraan masuk dan keluar sisi jalan, kendaraan lambat. Aturan-aturan mengenai kapasitas jalan Indonesia yang digunakan pada penelitian ini adalah Manual Kapasitas Jalan Indonesia 1997. Tangerang Selatan merupakan kota terbesar kedua di Provinsi Banten setelah kota Tangerang serta terbesar kelima di kawasan jabodetabek setelah Jakarta, Bekasi, Tangerang, dan Depok. Berdasarkan data PDRB tahun 2007, perekonomian Tangerang Selatan didominasi oleh sektor tersier (pengangkutan dan komunikasi, perdaganagan hotel dan restoran, jasa-jasa dan bank, persewaan dam jasa perusahaan), sehingga tuntutan penyediaan fasilitas pelayanan publik meningkat seiring aktivitas kota yang semakin berkembang. Karaktristik lalu lintas Kota Tangerang Selatan sangat dipengaruhi oleh fungsi - fungsi seperti perdagangan dan jasa, perkantoran, pendidikan, pabrik, dan aktivitas kendaraan umum yang banyak melintas.

Berdasarkan latar belakang, tujuan dari penelitian ini adalah menganalisis nilai hambatan samping pada tata guna lahan yang berbeda, menyusun korelasi antara tata guna lahan dengan nilai parameter hambatan samping dan mengevaluasi kategori kelompok hambatan samping.

\section{Hambatan Samping}

Hambatan samping yaitu aktivitas samping jalan yang dapat menimbulkan konflik dan berpengaruh terhadap pergerakan arus lalu lintas serta menurunkan fungsi kinerja jalan. Tipe hambatan samping terbagi menjadi:

1. Pejalan kaki

2. Kendaraan berhenti atau parkir

3. Kendaraan yang masuk dan keluar dari lahan samping jalan

4. Kendaraan lambat (MKJI,1997)

Tingkat hambatan samping dikelompokkan dalam lima kelas, dari kelas rendah sampai kelas tinggi sebagai fungsi dari kejadian hambatan samping di sepanjang jalan yang diamati. Nilai kelas hambatan samping dapat dilihat pada Tabel 1. 
Tabel 1. Nilai Kelas Hambatan Samping (MKJI,1997)

\begin{tabular}{|c|c|c|c|}
\hline $\begin{array}{l}\text { Kelas } \\
\text { Hambatan } \\
\text { Samping } \\
(\mathrm{SCF})\end{array}$ & Kode & $\begin{array}{l}\text { Jumlah } \\
\text { kejadian } \\
\text { per } 200 \mathrm{~m} \\
\text { per jam }\end{array}$ & Kondisi daerah \\
\hline Sangat Rendah & VL & $<100$ & $\begin{array}{l}\text { Daerah pemukiman; } \\
\text { hampir tidak ada kegitan }\end{array}$ \\
\hline Rendah & $\mathrm{L}$ & $100-299$ & $\begin{array}{l}\text { Daerah pemukiman; } \\
\text { berupa angkutan umum } \\
\text { dan sebagainya }\end{array}$ \\
\hline Sedang & M & $300-499$ & $\begin{array}{l}\text { Daerah industri; beberapa } \\
\text { toko di sisi jalan }\end{array}$ \\
\hline Tinggi & $\mathrm{H}$ & $500-899$ & $\begin{array}{l}\text { Daerah komersial; } \\
\text { aktivitas sisi jalan yang } \\
\text { sangat tinggi }\end{array}$ \\
\hline Sangat Tinggi & VH & $>900$ & $\begin{array}{l}\text { Daerah komersial; } \\
\text { aktivitas pasar di samping } \\
\text { jalan }\end{array}$ \\
\hline
\end{tabular}

Faktor-faktor yang mempengaruhi nilai kelas hambatan samping dengan frekuensi bobot kejadian per 200m dari segmen jalan yang diamati ppada kedua sisi jalan, seperti yang dijelaskan pada Tabel 2.

Tabel 2. Penentuan Tipe Frekuensi Kejadian Hambatan Samping (MKJI,1997)

\begin{tabular}{lcc}
\hline Tipe kejadian hambatan samping & Simbol & Faktor bobot \\
\hline Pejalan kaki & PED & 0,5 \\
Kendaraan parker & PSV & 1,0 \\
Kendaraan masuk dan keluar sisi jalan & EEV & 0,7 \\
Kendaraan lambat & SMV & 0,4 \\
\hline
\end{tabular}

\section{Tata Guna Lahan}

Tata guna lahan (land use) adalah setiap bentuk campur tangan (intervensi) manusia terhadap lahan untuk memenuhi kebutuhan hidupnya baik material maupun (Vink, 1975). Dalam rencana tata guna lahan suatu kota selain tercantum berbagai jenis pemanfaatan lahan, juga membahas tentang berbagai sarana \& prasarana yang dibutuhkan oleh suatu kota seperti jaringan jalan, listrik, air dan lain-lain. Penatagunaan lahan juga diatur oleh negara yang tertuang dalam Pasal 2 Peraturan Pemerintah Republik Indonesia No 16 Tahun 2004.

\section{Kapasitas Jalan}

Kapasitas jalan menurut MKJI 1997 didefinisikan sebagai arus maksimum yang melewati suatu titik pada jalan bebas hambatan yang dapat dipertahankan persatuan jam dalam kondisi yang berlaku. Kapasitas dinyatakan dalam kendaraan/jam atau smp/jam. Faktor-faktor yang mempengaruhi kapasitas jalan antara lain kondisi geomteri, kondisi lalu lintas dan kondisi lingkungan.

Penentuan kapasitas jalan, dapat diperoleh dari persamaan:

$$
C=\operatorname{Cox} F C w \times F C s p x F C s f \times F C c s
$$

dengan $\mathrm{C}=$ kapasitas, $\mathrm{Co}=$ kapasitas dasar, $\mathrm{FCw}=$ faktor penyesuaian lebar jalan, $\mathrm{FCsp}=$ factor penyesuaian pemisah arah, FCsf = faktor penyesuaian hambatan samping dan bahu jalan/kerb dan FCcs = faktor penyesuaian ukuran kota. 


\section{Kecepatan Arus Bebas}

Kecepatan arus bebas adalah kecepatan pada tingkat arus nol, yaitu kecepatan yang akan dipilih pengemudi jika mengendarai kendaraan bermotor tanpa dipengaruhi kendaraan yang lain (volume $=1$ ). Kecepatan arus bebas dapat dihitung dengan persamaan matematis yang terdapat pada MKJI (1997) dengan mempertimbangkan data geometrik serta kondisi lingkungan jalan. Untuk menghitung kecepatan arus bebas, persamaan yang digunakan adalah sebagai berikut:

$$
F V=(F V o+F V w) x F F V s f x F F V c s
$$

dengan FV = kecepatan arus bebas untuk kendaraan ringan dalam kondisi actual, FVo = kecepatan dasar arus bebas untuk kendaraan ringan, $\mathrm{FVw}$ = faktor penyesuaian kecepatan untuk lebar jalan, FFVsf = faktor penyesuaian untuk hambatan samping dan bahu jalan/kerb dan FFVcs = faktor penyesuaian kecepatan untuk ukuran kota.

\section{Tingkat Pelayanan (LoS)}

Tingkat pelayanan (LoS) adalah ukuran kualitatif yang mencerminkan persepsi pengemudi dan penumpang mengenai karakteristik kondisi operasional dalam arus lalu lintas (MKJI 1997).

\section{METODOLOGI PENELITIAN}

Sistematika proses penelitian merupakan tahappan penelitian yang harus dilakukan secara beruntun agar tujuan penelitian dapat dicapai sesuai yang diharapkan. Tahapan ppenelitian yang harus dilakukan adalah sebagai berikut:

Tahap I : Menentukan tujuan penelitian, tinjauan pustaka dan metodologi penelitian

Tahap II : Membuat formulir survei dan kuesioner

Tahap III : Melakukan pilot survei untuk kuesioner dan observasi lapangan

Tahap IV : : Melakukan revisi kuesioner

Tahap V : Melakukan pengumpulan data observasi dan kuesioner

Tahap VI : : Menganalisis data observasi dan data kuesioner

Tahap VII : Mencari hubungan antara hambatan samping dengan kecepatan dan volume lalu lintas dari data observasi

Tahap VIII : : Mencari tingkat gangguan hambatan samping dari masing-masing responden

Tahap IX : Menganalisis korelasi respon terhadap hambatan samping dengan hubungan hambatan samping terhadap kecepatan dan volume lalu lintas

Tahap X : Kesimpulan dan saran

\section{Metode Pengumpulan Data}

Metode survei lapangan diperoleh dari menyebarkan dan mengumpulkan data kuesioner. Responden yang dituju untuk kuesioner ini adalah orang yang ada di sekitar lokasi observasi atau yang minimal satu minggu sekali melewati wilayah penelitian. Selain itu metode observasi lapangan dilakukan per 200 meter pada wilayah penelitian selama 2 jam dan dicatat per 15 menit. Data-data yang diambil adalah volume lalu lintas (Sepeda Motor, Kendaraan Ringan, Kendaraan Berat), kecepatan lalu lintas, dan jumlah hambatan samping.

\section{Metode Analisis Data}

Metode yang digunakan untuk menganalisis data observasi adalah dengan menggunakan metode statistik yaitu metode korelasi pearson untuk mendapatkan korelasi antara volume lalu lintas dengan hambatan samping dan kecepatan lalu lintas dengan hambatan samping. Korelasi Person dihitung dengan bantuan Microsoft excel. 
Kuesioner diolah dengan mencari nilai rata-rata masing-masing hambatan samping sesuai dengan jawaban masingmasing responden dan dicari nilai $\mathrm{R}$ dari masing-masing hambatan samping. Setelah itu nilai $\mathrm{R}$ tersebut diurutkan sehingga menjadi urutan gangguan hambatan samping menurut responden.

\section{Kompilasi Data}

Data-data yang didapat terdiri dari:

1. Volume lalu lintas

2. Kecepatan lalu lintas

3. Jumlah masing-masing hambatan samping

4. Data kuesioner

\section{ANALISIS DATA}

Setelah dilakukan analisis data, diperoleh nilai kelas hambatan samping untuk Jalan MH. Thamrin Tangerang arah Tangerang dengan tata guna lahan pertokoan adalah low, karena jumlah berbobot kejadian per 200m per jam sebanyak 100-299 kejadian. Sedangkan Jalan Raya Serpong arah BSD dengan tata guna lahan perumahan dan pertokoan, kelas hambatan sampingnya adalah very-high karena jumlah berbobot kejadian per $200 \mathrm{~m}$ per jam >900 kejadian.

\section{Kapasitas Jalan}

Setelah didapat kelas hambatan samping masing-masing ruas jalan, dilakukan perhitungan kapasitas untuk masingmasing wilayah studi dengan menggunakan Persamaan 1. Hasil perhitungan kapasitas dapat dilihat pada Tabel 3 dan Tabel 4.

Tabel 3. Nilai Kapasitas Jalan MH. Thamrin Tangerang

\begin{tabular}{cccccc}
\hline \multicolumn{7}{c}{ KAPASITAS (SMP/JAM) } \\
\hline Co (SMP) & FCw & FCsp & FCsf & FCcs & C \\
\hline 4950 & 0.92 & 1 & 0.96 & 1 & 4371.84 \\
\hline
\end{tabular}

Tabel 4. Nilai Kapasitas Jalan Raya Serpong

\begin{tabular}{cccccc}
\hline \multicolumn{7}{c}{ KAPASITAS (SMP/JAM) } \\
\hline Co (SMP) & FCw & FCsp & FCsf & FCcs & C \\
\hline 4950 & 0.92 & 1 & 0.88 & 1 & 4007.52 \\
\hline
\end{tabular}

\section{Kecepatan Arus Bebas}

Dilakukan analisis kecepatan arus bebas dengan menggunakan Persamaan (2) dan melihat data-data yang diperlukan dari MKJI 1997. Hasil perhitungan kecepatan arus bebas masing-masing ruas jalan dapat dilihat di Tabel 5 dan Tabel 6.

Tabel 5. Kecepatan Arus Bebas Jalan MH. Thamrin Tangerang

\begin{tabular}{cccccc}
\hline \multicolumn{7}{c}{ Jalan MH. Thamrin Tangerang } \\
\hline Fvo & FVw & Fvo + FVw & FFVsf & FFVcs & FV \\
\hline 57 & -4 & 53 & 0.984 & 1.00 & 52.152 \\
\hline
\end{tabular}

Tabel 6. Kecepatan Arus Bebas Jalan Raya Serpong

\begin{tabular}{cccccc}
\hline \multicolumn{7}{c}{ Jalan Raya Serpong } \\
\hline Fvo & FVw & Fvo + FVw & FFVsf & FFVcs & FV \\
\hline 57 & -4 & 53 & 0.88 & 1.00 & 46.64 \\
\hline
\end{tabular}




\section{Hubungan Volume dan Kecepatan Lalu Lintas Dengan Hambatan Samping}

Untuk menghitung hubungan volume lalu lintas dengan hambatan samping digunakan metode korelasi pearson. Rumus korelasi pearson dapat dilihat pada Persamaan 3.

$$
R^{2}=\frac{\left\{n \sum(x y)-\sum x \sum y\right\}^{2}}{\left\{n \sum x^{2}-\left(\sum x\right)^{2}\right\}\left\{n \sum y^{2}-\left(\sum y\right)^{2}\right\}}
$$

dengan $\mathrm{R}=$ nilai korelasi pearson, $\mathrm{n}=$ jumlah kejadian, $\mathrm{x}=$ volume lalu lintas atau kecepatan lalu lintas dan $\mathrm{y}=$ jumlah hambatan samping.

Hasil analisis hubungan volume dan kecepatan lalu lintas dengan hambatan samping kemudian dibandingkan dengan bobot masing-masing hambatan samping yang terdapat di MKJI 1997. Hasil perbandingan dapat dilihat pada Tabel 7 dan 8 .

Tabel 7. Hasil Perbandingan Observasi dengan MKJI Jalan MH. Thamrin Tangerang

\begin{tabular}{|c|c|c|c|c|c|c|c|}
\hline \multirow{2}{*}{$\begin{array}{c}\text { Jalan Raya MH. } \\
\text { Thamrin Tangerang } \\
\text { Hambatan Samping }\end{array}$} & \multirow{2}{*}{$\begin{array}{l}\text { Bobot } \\
\text { MKJI }\end{array}$} & \multicolumn{3}{|c|}{$\begin{array}{l}\text { Nilai Korelasi } \\
\text { terhadap Volume }\end{array}$} & \multicolumn{3}{|c|}{$\begin{array}{c}\text { Nilai Korelasi terhadapp } \\
\text { Kecepatan }\end{array}$} \\
\hline & & Pagi & Siang & Sore & Pagi & Siang & Sore \\
\hline $\begin{array}{c}\text { Kendaraan Tidak } \\
\text { Bermotor }\end{array}$ & 0.40 & 0.45 & 0.34 & 0.37 & 0.39 & 0.84 & 0.59 \\
\hline Pejalan Kaki & 0.50 & 0.78 & 0.51 & 0.54 & 0.45 & 0.55 & 0.58 \\
\hline $\begin{array}{l}\text { Akses Keluar } \\
\text { Masuk }\end{array}$ & 0.70 & 0.41 & 0.43 & 0.38 & 0.66 & 0.37 & 0.61 \\
\hline Kendaraan Berhenti & 1 & 0.80 & 0.46 & 0.80 & 0.46 & 0.44 & 0.49 \\
\hline
\end{tabular}

Tabel 8. Hasil Perbandingan Observasi dengan MKJI Jalan Raya Serpong

\begin{tabular}{|c|c|c|c|c|c|c|c|}
\hline \multirow{2}{*}{$\begin{array}{l}\text { Jalan Raya Cideng II } \\
\text { Hambatan Samping }\end{array}$} & \multirow{2}{*}{$\begin{array}{l}\text { Bobot } \\
\text { MKJI }\end{array}$} & \multicolumn{3}{|c|}{$\begin{array}{l}\text { Nilai Korelasi terhadap } \\
\text { Volume }\end{array}$} & \multicolumn{3}{|c|}{$\begin{array}{c}\text { Nilai Korelasi terhadap } \\
\text { Volume }\end{array}$} \\
\hline & & Pagi & Siang & Sore & Pagi & Siang & Sore \\
\hline $\begin{array}{c}\text { Kendaraan Tidak } \\
\text { Bermotor }\end{array}$ & 0.40 & 0.44 & 0.57 & 0.30 & 0.53 & 0.57 & 0.42 \\
\hline Pejalan Kaki & 0.50 & 0.32 & 0.63 & 0.95 & 0.30 & 0.44 & 0.72 \\
\hline Akses Keluar Masuk & 0.70 & 0.68 & 0.63 & 0.74 & 0.51 & 0.56 & 0.58 \\
\hline Kendaraan Berhenti & 1 & 0.24 & 0.76 & 0.58 & 0.44 & 0.40 & 0.49 \\
\hline
\end{tabular}

\section{Analisis Data Kuesioner}

Kuesioner disebarkan sebanyak 25 kuesioner untuk masing-masing ruas jalan kepada responden yang minimal satu kali dalam seminggu melewati jalan tersebut. Data hasil kuesioner dapat dilihat pada Tabel 9 dan 10.

Tabel 9. Data Hasil Kuesioner Jalan MH.Thamrin Tangerang

\begin{tabular}{lcccccc}
\hline Butir Pernyataan & 1 & 2 & 3 & 4 & 5 & Rata-rata \\
\hline $\begin{array}{l}\text { Pejalan kaki - Kendaraan } \\
\text { Berhenti }\end{array}$ & 10 & 8 & 7 & 0 & 0 & 1.88 \\
$\begin{array}{l}\text { Pejalan kaki - Akses keluar } \\
\text { masuk }\end{array}$ & 9 & 11 & 5 & 0 & 0 & 1.84 \\
$\begin{array}{l}\text { Pejalan kaki - Kendaraan } \\
\text { tidak bermotor }\end{array}$ & 0 & 2 & 13 & 10 & 0 & 3.32 \\
$\begin{array}{l}\text { Kendaraan berhenti-akses } \\
\text { keluar/masuk }\end{array}$ & 0 & 0 & 5 & 15 & 5 & 4.00 \\
$\begin{array}{l}\text { Kendaraan berhenti - } \\
\text { Kendaraan tidak bermotor }\end{array}$ & 0 & 0 & 2 & 6 & 17 & 4.60 \\
$\begin{array}{l}\text { Akses keluar masuk - } \\
\text { kendaraan tidak bermotor }\end{array}$ & 0 & 0 & 6 & 19 & 0 & 3.76 \\
\hline
\end{tabular}


Tabel 10. Data Hasil Kuesioner Jalan Raya Serpong

\begin{tabular}{lcccccc}
\hline Butir Pernyataan & 1 & 2 & 3 & 4 & 5 & Rata-rata \\
\hline $\begin{array}{l}\text { Pejalan kaki }- \text { Kendaraan } \\
\text { Berhenti }\end{array}$ & 22 & 3 & 0 & 0 & 0 & 1.12 \\
$\begin{array}{l}\text { Pejalan kaki - Akses keluar } \\
\text { masuk }\end{array}$ & 25 & 0 & 0 & 0 & 0 & 1.00 \\
$\begin{array}{l}\text { Pejalan kaki - Kendaraan } \\
\text { tidak bermotor }\end{array}$ & 17 & 4 & 4 & 0 & 0 & 1.48 \\
$\begin{array}{l}\text { Kendaraan berhenti-akses } \\
\text { keluar/masuk }\end{array}$ & 19 & 4 & 2 & 0 & 0 & 1.32 \\
$\begin{array}{l}\text { Kendaraan berhenti - } \\
\text { Kendaraan tidak bermotor } \\
\text { Akses keluar masuk - } \\
\text { kendaraan tidak bermotor }\end{array}$ & 0 & 0 & 2 & 8 & 15 & 4.52 \\
\hline
\end{tabular}

\section{Perbandingan Urutan Hambatan Samping Hasil Observasi, Kuesioner dan MKJI}

Dilakukan perbandingan urutan parameter-parameter hambatan samping yang didapat dari hasil analisis data observasi. kuesioner dengan MKJI. Hambatan samping diurutkan dari yang paling kecil sampai yang paling besar bobotnya. Urutan hambatan samping dapat dilihat pada Tabel 11 dan 12.

Tabel 11. Jalan Raya MH.Thamrin Tangerang

\begin{tabular}{|c|c|c|c|c|c|c|c|c|}
\hline \multirow{2}{*}{$\begin{array}{l}\text { MH. Thamrin Tangerang } \\
\text { Hambatan Samping }\end{array}$} & \multirow{2}{*}{$\begin{array}{l}\text { Bobot } \\
\text { MKJI }\end{array}$} & \multirow{2}{*}{$\begin{array}{l}\text { Bobot } \\
\text { Kuesioner }\end{array}$} & \multicolumn{3}{|c|}{$\begin{array}{c}\text { Nilai Korelasi terhadap } \\
\text { volume }\end{array}$} & \multicolumn{3}{|c|}{$\begin{array}{c}\text { Nilai Korelasi terhadap } \\
\text { Kecepatan }\end{array}$} \\
\hline & & & Pagi & Siang & Sore & Pagi & Siang & Sore \\
\hline Kendaraan Tidak Bermotor & 0.4 & 0.04 & 0.45 & 0.34 & 0.37 & 0.39 & 0.84 & 0.59 \\
\hline Pejalan Kaki & 0.5 & 0.33 & 0.78 & 0.51 & 0.54 & 0.45 & 0.55 & 0.58 \\
\hline Akses Keluar Masuk & 0.7 & 0.21 & 0.41 & 0.43 & 0.38 & 0.66 & 0.37 & 0.61 \\
\hline Kendaraan Berhenti & 1 & 0.42 & 0.80 & 0.46 & 0.80 & 0.46 & 0.44 & 0.49 \\
\hline
\end{tabular}

Tabel 12. Jalan Raya Serpong

\begin{tabular}{|c|c|c|c|c|c|c|c|c|}
\hline \multirow{2}{*}{$\begin{array}{l}\text { Jalan Raya Serpong } \\
\text { Hambatan Samping }\end{array}$} & \multirow{2}{*}{$\begin{array}{l}\text { Bobot } \\
\text { MKJI }\end{array}$} & \multirow{2}{*}{$\begin{array}{c}\text { Bobot } \\
\text { Kuesioner }\end{array}$} & \multicolumn{3}{|c|}{$\begin{array}{c}\text { Nilai Korelasi terhadap } \\
\text { volume }\end{array}$} & \multicolumn{3}{|c|}{$\begin{array}{c}\text { Nilai Korelasi terhadap } \\
\text { Kecepatan }\end{array}$} \\
\hline & & & Pagi & Siang & Sore & Pagi & Siang & Sore \\
\hline Kendaraan Tidak Bermotor & 0.4 & 0.05 & 0.44 & 0.57 & 0.30 & 0.53 & 0.57 & 0.42 \\
\hline Pejalan Kaki & 0.5 & 0.20 & 0.32 & 0.63 & 0.95 & 0.30 & 0.44 & 0.72 \\
\hline Akses Keluar Masuk & 0.7 & 0.370 & 0.68 & 0.63 & 0.74 & 0.51 & 0.56 & 0.58 \\
\hline Kendaraan Berhenti & 1 & 0.375 & 0.24 & 0.76 & 0.58 & 0.44 & 0.40 & 0.49 \\
\hline
\end{tabular}

\section{KESIMPULAN}

Berdasarkan hasil penelitian, dapat ditarik kesimpulan sebagai berikut:

1. Urutan nilai bobot hambatan samping dari MKJI 1997 berbeda dengan hasil analisis kuesioner. Pada MKJI 1997 urutan dan bobotnya adalah kendaraan tidak bermotor (0.4), pejalan kaki (0.5), akses keluar masuk (0.7), kendaraan berhenti (1). Sedangkan hasil analisis kuesioner pada Jalan MH. Thamrin Tangerang urutan serta bobot masing-masing parameter hambatan samping adalah kendaraan tidak bermotor (0.04), akses keluar masuk (0.21), pejalan kaki (0.33), pejalan kaki $(0.42)$.

2. Urutan nilai bobot hambatan samping dari MKJI 1997 berbeda dengan hasil analisis kuesioner. Pada MKJI 1997 urutan dan bobotnya adalah kendaraan tidak bermotor (0.4), pejalan kaki (0.5), akses keluar masuk (0.7), kendaraan berhenti (1). Sedangkan hasil analisis kuesioner pada Jalan Raya Serpong urutan serta bobot masing-masing parameter hambatan samping adalah kendaraan tidak bermotor (0.05), pejalan kaki (0.20), akses keluar masuk (0.370), kendaraan berhenti (0.375). 
3. Dari hasil analisis, diperoleh nilai koefisien terbesar pada ruas Jalan MH.Thamrin Tangerang terletak pada hubungan hambatan samping kendaraan tidak bermotor pada siang hari terhadap kecepatan, yaitu sebesar 0.84. Sedangkan nilai koefisien terkecil terletak pada hubungan hambatan samping kendaraan tidak bermotor pada siang hari terhadap volume dengan nilai $\mathrm{R}$ sebesar 0.34 .

4. Dari hasil analisis, diperoleh nilai koefisien terbesar pada ruas Jalan Raya Serpong terletak pada hubungan hambatan samping pejalan kaki pada sore hari terhadap volume, yaitu sebesar 0.95. Sedangkan nilai koefisien terkecil terletak pada hubungan hambatan samping kendaraan berhenti ppada pagi hari terhadap volume dengan nilai R sebesar 0.24.

5. Perbedaan bobot antara parameter hambatan samping dengan bobot hambatan samping yang terdapat di dalam MKJI 1997 menunjukan bahwa MKJI 1997 kurang tepat bila diterapkan di semua ruas jalan. Karena bobot masing-masing parameter hambatan samping tergantung pada aktivitas tata guna lahan di sekitarnya.

\section{DAFTAR PUSTAKA}

Direktorat Jenderal Bina Marga. (1997). Manual Kapasitas Jalan Indonesia. Direktorat Jenderal Bina Marga, Jakarta. Kusbiantoro, B. S. (2007). Perencanaan, Pemodelan dan Rekayasa Transportasi. Bandung

Marunseng, G. S. (2015). Pengaruh Hambatan Samping Terhadap Kinerja Pada Ruas Jalan Panjaitan dengan Menggunakan Metode MKJI 1997.Manado.

Morlok, E.K. (1981). Pengantar Teknik dan Perencanaan Transportasi. Erlangga, Jakarta

Sugiyono. (2008). Metode Penelitian Kuantitatif Kualitatif dan R\&D. Alfabeta, Bandung

Tamin, O.Z. (2000). Perencanaan dan Pemodelan Transportasi, Edisi kedua. Jurusan Teknik Sipil Institut Teknologi Bandung, Bandung

Wibawa, B.A. (1996). Tata Guna Lahan dan Transportasi Dalam Pembangunan Berkelanjutan. Universitas Diponegoro, Semarang. 
